\title{
Population-level effects of abamectin, azadirachtin and fenpyroximate on the predatory mite Neoseiulus baraki
}

\author{
Debora B. Lima ${ }^{1,5} \cdot$ José W. S. Melo $^{2}$ - Manoel G. C. Gondim Jr. ${ }^{1}$ • \\ Raul N. C. Guedes ${ }^{3} \cdot$ José E. M. Oliveira $^{4}$
}

Received: 29 April 2015/Accepted: 18 July 2016/Published online: 5 August 2016

(C) Springer International Publishing Switzerland 2016

\begin{abstract}
The coconut production system, in which the coconut mite Aceria guerreronis is considered a key pest, provides an interesting model for integration of biological and chemical control. In Brazil, the most promising biological control agent for the coconut mite is the phytoseiid predator Neoseiulus baraki. However, acaricides are widely used to control the coconut mite, although they frequently produce unsatisfactory results. In this study, we evaluated the simultaneous direct effect of dry residue contact and contaminated prey ingestion of the main acaricides used on coconut palms (i.e., abamectin, azadirachtin and fenpyroximate) on life-history traits of $N$. baraki and their offspring. These acaricides are registered, recommended and widely used against $A$. guerreronis in Brazil, and they were tested at their label rates. The offspring of the exposed predators was also evaluated by estimating the instantaneous rate of population increase $\left(r_{i}\right)$. Abamectin compromised female performance, whereas fenpyroximate did not affect the exposed females (F0). Nonetheless, fenpyroximate strongly compromised the offspring (F1) net reproductive rate $\left(\mathrm{R}_{0}\right)$, intrinsic rate of population growth $\left(r_{i}\right)$, and doubling time (DT). In contrast, fenpyroximate did not have such effects on the 2 nd generation (F2) of predators with acaricideexposed grandparents. Azadirachtin did not affect the predators, suggesting that this acaricide can be used in association with biological control by this predatory species. In contrast, the use of abamectin and fenpyroximate is likely to lead to adverse consequences in the biological control of A. guerreronis using $N$. baraki.
\end{abstract}

Debora B. Lima

deboralima_85@yahoo.com.br

1 Departamento de Agronomia - Entomologia, Universidade Federal Rural de Pernambuco, Av. Dom Manuel de Medeiros s/n, Dois Irmãos, Recife, PE 52171-900, Brazil

2 Departamento de Fitotecnia, Universidade Federal do Ceará, Fortaleza, CE, Brazil

3 Departamento de Entomologia, Universidade Federal de Viçosa, Av. Peter Henry Rolfs, s/n, Campus Universitário, Viçosa, MG 36570-000, Brazil

4 Laboratório de Entomologia, Embrapa Semiárido, Petrolina, PE 56302-970, Brazil

5 Departamento de Agronomia (Fitossanidade), Universidade Federal Rural de Pernambuco, Av. Dom Manuel de Medeiros s/n, Bairro Dois Irmãos, Recife, PE 52.171-900, Brazil 
Keywords Demographic toxicology · Coconut · Aceria guerreronis · Phytoseiidae · Integrated pest management

\section{Introduction}

Predatory mites are considered effective natural enemies of phytophagous mites (Helle and Sabelis 1985; McMurtry and Croft 1997; McMurtry et al. 2013). Many predatory mite species are specialized feeders and are able to respond to the population dynamics of particular species (Solomon et al. 2010), such as specialized mite predators (type I predators according to McMurtry et al. 2013). However, they are frequently unable to fully and reliably prevent pest damage when used as a sole management tactic (Solomon et al. 2010). In such cases, alternative strategies are needed to control mite pests. The control of phytophagous mites is frequently performed almost exclusively using acaricides (Watanabe et al. 1994). Nevertheless, this is an expensive management tactic that requires periodic acaricide applications and the purchase of suitable equipment and supplies. Thus, given its high cost, the use of acaricides can be economically prohibitive for small-scale farmers. In such low-input production systems (systems that receive no or low cash inflows), the integration between predatory mites and acaricides becomes an economically viable option. For this integration to be possible, acaricides with low (or no) negative impacts on predatory mites are required. As the coconut production system permits the potential integration of these management tactics, it is a suitable model for studying such integration.

The coconut Cocos nucifera L. suffers from attack by several pests. Among these, the coconut mite Aceria guerreronis Keifer (Acari: Eriophyidae) is considered a key pest of coconut palms (Moore and Howard 1996; Haq et al. 2002). Several countries have reported losses of up to $60 \%$ due to this pest (Negloh et al. 2011; Navia et al. 2013; Rezende et al. 2016). The coconut mite causes damage by feeding on the fruit perianth, an enclosed region under the bracts where the mite develops. The fruit surface becomes necrotic and can eventually result in premature fruit fall, reducing the number of fruits in the bunch (Moore and Howard 1996). The most common method of control for this pest is based on intensive acaricide use, but because this pest lives well protected under the floral bracts, the efficacy achieved using acaricides is not always satisfactory (Moore and Howard 1996; Ramaraju et al. 2002; Monteiro et al. 2012; Silva et al. 2016). Monteiro et al. (2012) suggest that control of the coconut mite using pesticides should only be implemented while the mites are dispersing by walking over sprayed fruit.

Biological control is gaining attention as a management alternative for coconut mites (Domingos et al. 2010; Lima et al. 2012). The most promising biological control agent for the coconut mite is Neoseiulus baraki (Athias-Henriot) (Acari: Phytoseiidae) (Aratchige et al. 2007; Negloh et al. 2008; Domingos et al. 2010; Melo et al. 2011; Lima et al. 2012). This predator has easier access to the microhabitat inhabited by the pest compared with other predators, and it exhibits a progressively higher predation rate of the coconut mite (Lima et al. 2012). Neoseiulus baraki has been tested in field inundative releases by Fernando et al. (2010), who reported that a single release of $N$. baraki in coconut palms provides significant reduction of the coconut mite population.

Within this context, understanding the potential effects of the acaricides used against the coconut mite on its predator $N$. baraki is fundamental for the integration of chemical and 
biological control. Fenpyroximate and chlorfenapyr appear to be selective to $N$. baraki over A. guerreronis (Lima et al. 2013a). However, there is no information on the potential impacts of acaricides on the life history traits and demography of $N$. baraki. Information on demographic toxicology involves the ecological and toxicological parameters that predict the overall effect of toxins at the population level (Ahmadi 1983; Stark and Wennergren 1995; Guedes et al. 2016). Fecundity and population growth have been used as indicators of mite population performance. The latter is a more robust toxicological endpoint than typical mortality assessments because it includes assessments of fertility and the mortality and birth rates in a given population (Saito 1979; Sabelis 1985; Stark and Wennergren 1995; Stark et al. 1997; Ansaloni et al. 2007; Walthall and Stark 1997). The evaluation of the life table parameters of predators after exposure to acaricides is helpful for the selection of suitable acaricides with minimal non-target toxicity. In this study, we evaluated the effects of widely used acaricides (abamectin, azadirachtin and fenpyroximate) that are recommended by the Brazilian Ministry of Agriculture against A. guerreronis (Agrofit 2015) on the life history traits of $N$. baraki and their 1st (F1) and 2nd (F2) generation offspring.

\section{Materials and methods}

\section{Establishment and maintenance of predator colonies}

Coconuts were collected from the coastal island of Itamaracá ("Ilha de Itamaracá"), State of Pernambuco, Brazil $\left(07^{\circ} 46^{\prime} \mathrm{S}, 34^{\circ} 52^{\prime} \mathrm{W}\right)$, and transported to the laboratory. The area is not commercially used; thus, it has not been subjected to pesticide applications or coconut mite control for over 10 years. Coconuts and mites were collected from 10 plants in the area. The fruits were maintained under controlled laboratory conditions $\left(27 \pm 1{ }^{\circ} \mathrm{C}\right.$, $70 \pm 10 \%$ relative humidity $[\mathrm{RH}]$ and a $12 \mathrm{~h}$ photoperiod). Neoseiulus baraki colonies were established using approximately 100 females collected from coconut fruits and transferred to rearing units. Each rearing unit consisted of a black PVC disk $(13 \mathrm{~cm}$ in diameter, $1 \mathrm{~mm}$ thick) laid on a foam mat disk that lined the bottom of a plastic tray. The margin of the PVC disk was covered using a band of hydrophilic cotton, and both the foam mat and the cotton band were kept wet by daily additions of distilled water to the tray. Aceria guerreronis was provided as food on a piece of perianth (approximately $1 \mathrm{~cm}^{2}$ ) obtained from the collected coconut fruits. Three hundred coconut mites were placed on each piece of perianth, which was replaced every 2 days to prevent the perianth from drying out, which would cause the coconut mites to starve to death. Five pieces of perianth were placed in each rearing unit. The units were maintained in a rearing chamber under the environmental conditions described above.

\section{Acaricides}

Azadirachtin, fenpyroximate and abamectin are registered and recommended by the Brazilian Ministry of Agriculture for use against A. guerreronis and widely used by coconut farmers (Agrofit 2015). These compounds were used in their respective commercial formulations as follows: azadirachtin (Azamax, $1.2 \mathrm{~g}$ a.i. [active ingredient]/L, emulsifiable concentrate, DAV Agro, Ituverava, SP, Brazil), fenpyroximate (Ortus, $50 \mathrm{~g}$ a.i./L, suspension concentrate, Arysta Lifescience, Salto de Pirapora, SP, Brazil), and 
abamectin (Vertimec, $18 \mathrm{~g}$ a.i./L, emulsifiable concentrate, Syngenta, São Paulo, SP, Brazil). The acaricides were tested at a single rate, the maximum label rate for the coconut mite in Brazil (Agrofit 2015), and their corresponding concentrations used in our experiments were $30 \mathrm{mg}$ a.i./L for azadirachtin, $100 \mathrm{mg}$ a.i./L for fenpyroximate, and $13.5 \mathrm{mg}$ a.i./L for abamectin (Agrofit 2015).

\section{Effects of acaricides on the life history traits of the treated unmated females (F0)}

Pieces of coconut perianth $\left(0.5 \mathrm{~cm}^{3}\right)$, individual wells (i.e., cells) of bioassay trays and adhesive covers (128 cells; Bio-Serv, Frenchtown, NJ, USA) were immersed in water (control) or one of each of the acaricide solutions recommended for the coconut mite for $5 \mathrm{~s}$ and allowed to air-dry for $2 \mathrm{~h}$ (Lima et al. 2013a). Then, a treated piece of perianth was placed in each cell and $300 \mathrm{~A}$. guerreronis were transferred onto each treated piece of perianth food source for the predators. One $N$. baraki female ( $12 \mathrm{~h}$ old) was transferred to each well and confined for $24 \mathrm{~h}$. Treated adhesive covers were used to seal each well to prevent the mites from escaping. The wells were placed in a rearing chamber and maintained at $27 \pm 1{ }^{\circ} \mathrm{C}$ and $70 \pm 10 \% \mathrm{RH}$ and a $12 \mathrm{~h}$ daily photoperiod. After $24 \mathrm{~h}$, the surviving females were transferred to untreated wells. An untreated male was also transferred to each (untreated) well containing a female to allow mating. The food was replenished every day with a new piece of perianth with coconut mites. Forty replicates were performed for each acaricide following a completely randomized design where each female represented one replicate.

Fertility and the pre-oviposition, oviposition, and post-oviposition periods were monitored, and data were recorded daily until female death. The males that died were replaced with new ones. For each treatment, the number of eggs per female $\left(\mathrm{m}_{\mathrm{x}}\right)$ on each oviposition date $(\mathrm{x})$ was calculated considering the total number of females, the cumulative survival rate of females $\left(1_{\mathrm{x}}\right)$ during the oviposition period, and the number of adult offspring of $\mathrm{x}$ age in the next generation $\left(1_{\mathrm{x}} \cdot \mathrm{m}_{\mathrm{x}}\right)$. Using this information $\left(\mathrm{m}_{\mathrm{x}}, \mathrm{l}_{\mathrm{x}}\right.$ and $\left.\mathrm{l}_{\mathrm{x}} \cdot \mathrm{m}_{\mathrm{x}}\right)$, the following parameters were estimated: net reproductive rate $\left(R_{0}=\sum l_{x} m_{x}\right)$, mean generation time $\left(T=\frac{\sum x l_{x} m_{x}}{\sum l_{x} m_{x}}\right)$, intrinsic rate of increase $\left(r_{m}=\frac{\operatorname{Ln}\left(R_{0}\right)}{T}\right)$ and doubling time $\left(D T=\frac{\operatorname{Ln}\left(R_{0}\right)}{r_{m}}\right)$; the latter refers to the time needed to double the initial population.

The fertility and the pre-oviposition, oviposition, and post-oviposition periods were analysed using the Kruskal-Wallis test with the NPAR1WAY procedure (SAS Institute 2008). The survival data were used to construct time-mortality curves using Kaplan-Meier estimators with the LIFETEST procedure (SAS Institute 2008), and log-rank tests were used for pairwise planned comparisons. The median survival times were analysed using the Kruskal-Wallis test employing the NPAR1WAY procedure (SAS Institute 2008). The "jackknife" technique was used to estimate the confidence intervals to compare life table parameters (Maia et al. 2000). A $\chi^{2}$ analysis was performed to determine whether there was any deviation from the expected sex ratio of 1:1 using the FREQ procedure (SAS Institute 2008).

\section{Effects of acaricides on the development and reproductive performance of the offspring (F1) of treated females}

Eggs from untreated (control) and treated females were transferred individually into untreated wells. Each subsequent stage was checked daily, and the developmental time and survival were recorded. When the adults emerged, they were sexed, and the females were 
separated. Males were subsequently added and paired with the females. Coconut mites were provided as food on a piece of perianth (approximately $1 \mathrm{~cm}^{2}$ ) containing nearly 300 individuals. The food was changed every day.

The developmental time (from egg to adulthood) and juvenile survival (proportion of eggs reaching adulthood) were subjected to Kaplan-Meier survival analysis using the LIFETEST procedure (SAS Institute 2008) to identify the overall effect, and log-rank tests were used for planned pairwise comparisons (Hosmer and Lemeshow 1999). The fertility, pre-oviposition, oviposition, and post-oviposition periods were analysed using the Kruskal-Wallis test employing the NPAR1WAY procedure (SAS Institute 2008). The survival data of the adults were used to construct time-mortality curves using Kaplan-Meier estimators, employing the LIFETEST procedure (SAS Institute 2008), and log-rank tests were used for planned pairwise comparisons. Using the developmental time, viability and female oviposition data, lifetables were constructed and analysed for each treatment as specified in the experiments described in subsection "Effects of acaricides on biological parameters of the treated unmated females (F0)".

\section{Effects of acaricides on the offspring (F2) of F1 females of Neoseiulus baraki}

The eggs laid by the F1 females (Bioassay: "Effect of acaricides on the developmental and reproductive performance of the offspring of treated females") were collected daily to determine and compare the instantaneous rate of increase $\left(r_{i}\right)$ of the following generation (F2). Every egg was transferred to a new untreated well, placed in a rearing chamber and maintained at $27 \pm 1{ }^{\circ} \mathrm{C}$ and $70 \pm 10 \% \mathrm{RH}$ and a $12 \mathrm{~h}$ daily photoperiod until they reached adulthood. Coconut mites were provided as food on a piece of perianth (approximately $1 \mathrm{~cm}^{2}$ ) containing nearly 300 individuals. When the females emerged, one male was added to each well. Fifteen replicates were performed for each acaricide, and every female represented one replicate. The numbers of eggs, larvae, nymphs and adults were recorded for 10 days. The instantaneous rate of increase $\left(r_{i}\right)$ was estimated using the following equation: $r_{i}=\ln ^{\left(\mathrm{N}_{\mathrm{f}} / \mathrm{N}_{0}\right)} / \Delta \mathrm{t}$, where $\mathrm{N}_{\mathrm{f}}$ is the final number of live mites, $\mathrm{N}_{0}$ is the initial number of live mites and $\Delta \mathrm{t}$ is the time interval between the start and end of the bioassay (Stark et al. 1997; Walthall and Stark 1997), which was carried out for 10 days. Positive $r_{i}$ values indicate that the population is growing, $r_{i}=0$ indicates that the population is stable, and negative $r_{i}$ values indicate that the population is in decline. The instantaneous rate of increase was analysed using the Kruskal-Wallis test employing the NPAR1WAY procedure (SAS Institute 2008).

\section{Results}

\section{Effects of acaricides on the biological parameters of the treated unmated females (FO)}

The exposure of $N$. baraki females to the acaricides did not affect the pre-oviposition period $\left(\chi^{2} \geq 0.17 ; d f=1 ; P \geq 0.06\right)$. However, significant differences were observed for the oviposition $\left(\chi^{2}=28.10 ; d f=3 ; P<0.001\right)$ and post-oviposition periods $\left(\chi^{2}=18.11\right.$; $d f=3 ; P<0.001$ ). Both periods (oviposition and post-oviposition) were shorter when the females were treated with abamectin. In addition, this product was the only one that 
affected the number of eggs per female $\left(\chi^{2}=28.15 ; d f=3 ; P<0.001\right)$, which decreased by $96 \%$ (Table 1 ).

Abamectin was the only acaricide that caused changes in the survival curves $\left(\chi^{2}=134.32 ; d f=3 ; P<0.001\right)$ and consequently decreased the median survival time $\left(\chi^{2}=27.15 ; d f=3 ; P<0.001\right)$ of $N$. baraki (Fig. 1a, b). This pesticide reduced survival by $76.7 \%$ and the median survival time by $84 \%$. Adult $N$. baraki did not survive longer than 7 days after exposure to abamectin, and the median survival time was $3.5 \pm 0.4$ days.

The $\mathrm{R}_{0}$ was negatively affected by abamectin and was reduced by $96.52 \%$. Although the other parameters were not affected when $N$. baraki was exposed to abamectin, these parameters were consistently (numerically) lower, and $r_{m}$ and DT were negative. The values of $r_{m}$, T and DT did not differ among the treatments (Table 2). The number of female offspring of $N$. baraki was consistently higher than the number of male offspring, except when females were exposed to abamectin, in which case the only two viable eggs produced males (Table 3).

\section{Effects of acaricides on the development and reproductive performance of the offspring (F1) of treated females}

It was not possible to analyse the developmental time, juvenile survival or life-table parameters of offspring of abamectin-treated females of $N$. baraki because only two F0 eggs were viable, and these eggs produced males. For the other acaricides, there was no effect of the exposed $N$. baraki females on the developmental rate of their offspring (Fig. 2; $\chi^{2}=0.66, d f=2, P=0.72$ ), but there was a significant effect on juvenile survival (Fig. $2 ; \chi^{2}=6.84, d f=2, P=0.03$ ). This was caused by the lower survival of juveniles from fenpyroximate-exposed females compared with unexposed (control) or azadirachtinexposed females (Fig. $2 ; \chi^{2}>4.38, d f=1, P<0.04$ ).

The survival curves of the offspring of acaricide-exposed females were not significantly different from those of the offspring of unexposed females $\left(\chi^{2}=1.40 ; d f=2 ; P=0.49\right)$. There were significant acaricide effects on the $\mathrm{R}_{0}, \mathrm{r}_{\mathrm{m}}$ and DT of the offspring of the exposed $N$. baraki females compared to those of the offspring of unexposed females (Table 4). Fenpyroximate was the only acaricide that significantly reduced the $R_{0}$ and $r_{m}$ of the offspring compared with the offspring of azadirachtin-treated and untreated females. As a consequence, the offspring of females exposed to fenpyroximate had a higher DT. There was no effect of acaricide exposure on the generation time (T) of $N$. baraki females compared to those of the offspring of unexposed females.

Table 1 Effects of sublethal exposure of acaricides on the mean $( \pm S E)$ reproductive performance and female longevity of Neoseiulus baraki

\begin{tabular}{lcrrr}
\hline Parameters & \multicolumn{2}{l}{ Treatments } & & \\
\cline { 2 - 5 } & \multicolumn{1}{l}{ Control } & Abamectin & Azadirachtin & Fenpyroximate \\
\hline Period of pre-oviposition (days) & $1.3 \pm 0.16 \mathrm{a}$ & $2.9 \pm 0.38 \mathrm{a}$ & $4.9 \pm 1.84 \mathrm{a}$ & $2.0 \pm 0.29 \mathrm{a}$ \\
Period of oviposition (days) & $15.5 \pm 1.7 \mathrm{a}$ & $0.6 \pm 0.16 \mathrm{~b}$ & $11.6 \pm 0.16 \mathrm{a}$ & $13.5 \pm 0.16 \mathrm{a}$ \\
Period of post-oviposition (days) & $1.7 \pm 0.90 \mathrm{a}$ & $0.1 \pm 0.16 \mathrm{~b}$ & $1.7 \pm 0.16 \mathrm{a}$ & $2.3 \pm 0.16 \mathrm{a}$ \\
Total number of eggs/females & $24.1 \pm 2.71 \mathrm{a}$ & $1.0 \pm 0.64 \mathrm{~b}$ & $20.4 \pm 3.23 \mathrm{a}$ & $22.9 \pm 4.10 \mathrm{a}$ \\
\hline
\end{tabular}

Means within a row followed by different letters are significantly different (Kruskal-Wallis tests: $P<0.05$ ) 

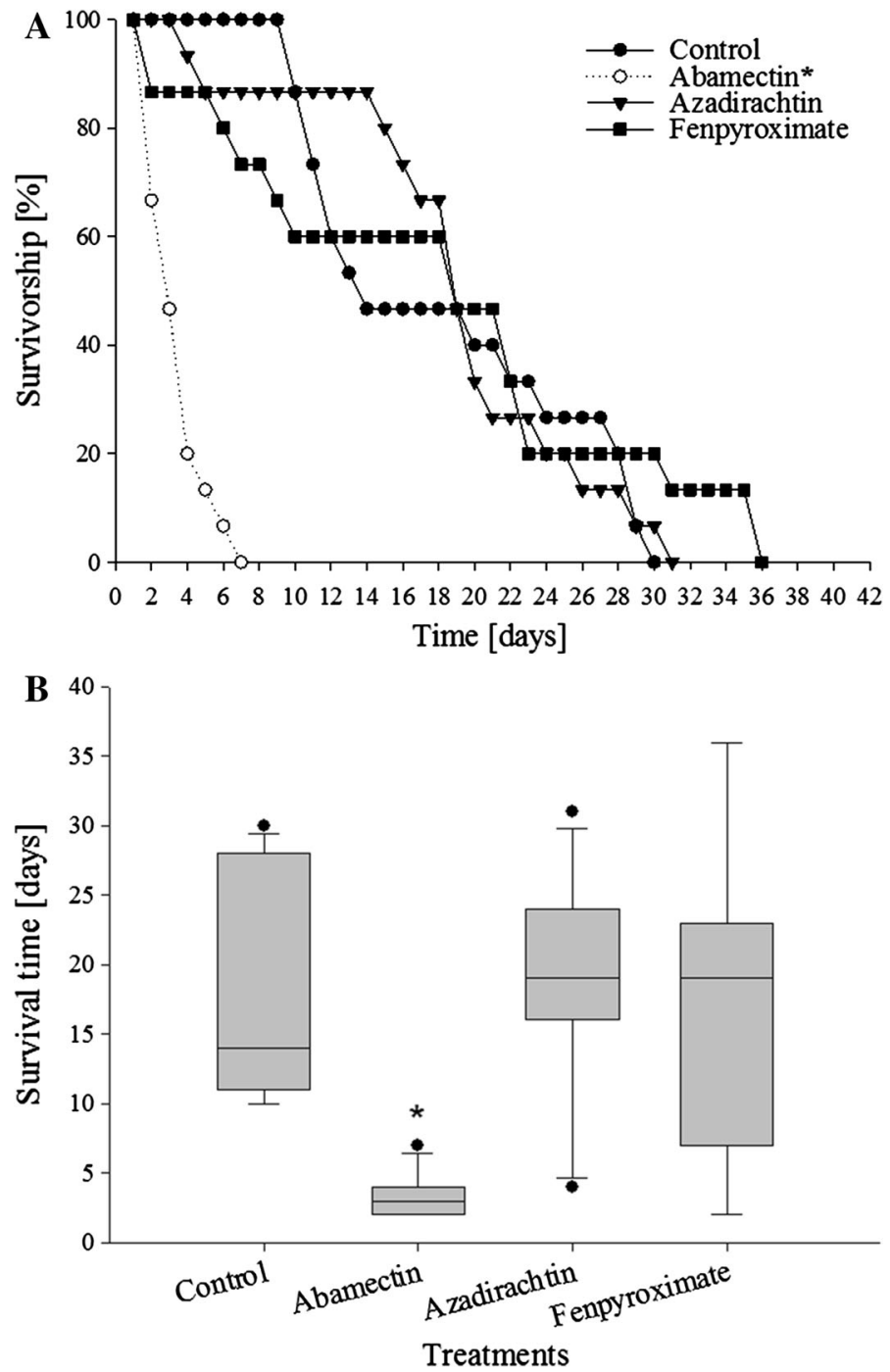

Fig. 1 a Survival curves of Neoseiulus baraki and b respective median survival times when exposed to abamectin, azadirachtin and fenpyroximate. The asterisk indicates a significant difference between acaricide-exposed and unexposed predators (log-rank test: $P<0.05$ ). The bottom and top of the boxes are the lower and upper quartiles, respectively, and the horizontal line near the middle of the box is the median; the whiskers represent the lowest and highest data points within an interquartile range of 1.5 from the first and third quartiles, respectively. Outliers are represented as dots

\section{Effects of acaricides on the second generation of exposed Neoseiulus baraki}

The $r_{i}$ value of the second generation of the acaricide-exposed females was not significantly different from the control $\left(\chi^{2}=4.70 ; d f=2 ; P=0.09\right)$. The $r_{i}$ values were as follows: control $=0.22 \pm 0.01$, azadirachtin $=0.20 \pm 0.01$ and fenpyroximate $=0.21 \pm 0.01$. 


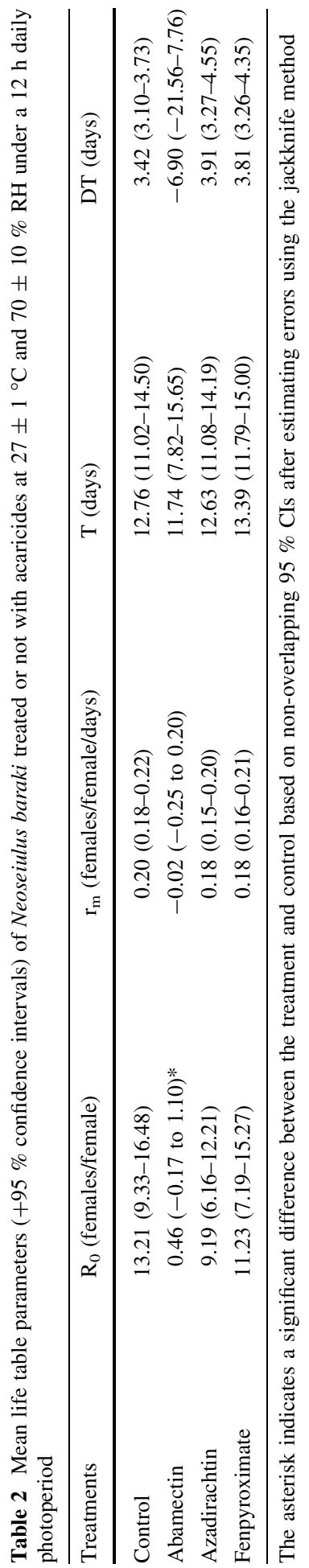


Table 3 Effects of sublethal exposure of acaricides on the sex ratio of Neoseiulus baraki tested by the $\chi^{2}$ goodness-of-fit test to a 1:1 (female:male) ratio*

\begin{tabular}{|c|c|c|c|c|c|c|c|c|}
\hline \multirow[t]{2}{*}{ Treatments } & \multicolumn{2}{|c|}{ Observed frequency } & \multicolumn{2}{|c|}{ Expected frequency } & \multirow[t]{2}{*}{$d f$} & \multirow[t]{2}{*}{$\chi^{2}$} & \multirow[t]{2}{*}{$\mathrm{P}$} & \multirow{2}{*}{$\begin{array}{l}\text { Female/ } \\
(\text { male }+ \text { female })\end{array}$} \\
\hline & Female & Male & Female & Male & & & & \\
\hline Control & 15 & 4 & 9.5 & 9.5 & 1 & 6.36 & 0.01 & 0.78 \\
\hline Abamectin & 0 & 2 & 1.0 & 1.0 & - & - & - & - \\
\hline Azadirachtin & 15 & 2 & 8.5 & 8.5 & 1 & 9.94 & 0.002 & 0.88 \\
\hline Fenpyroximate & 15 & 6 & 10.5 & 10.5 & 1 & 3.86 & 0.049 & 0.71 \\
\hline
\end{tabular}

* The real sex ratio for $N$. baraki is 0.80 [Female/(male + female)] (Domingos et al. 2010)

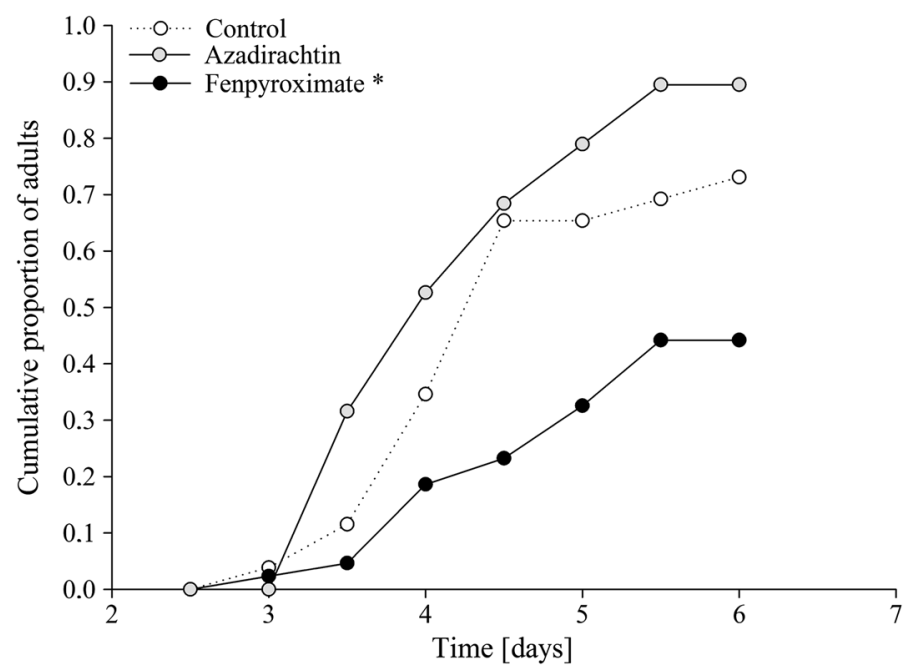

Fig. 2 Proportion of offspring of Neoseiulus baraki developing to adults after female exposure to acaricides (azadirachtin and fenpyroximate) or water (control). There were no significant differences in offspring developmental time (days). The asterisk indicates a significant difference in the cumulative proportion of adults (log-rank test: $P<0.05)$

\section{Discussion}

Three acaricides registered at the Ministry of Agriculture and widely used against the coconut mite in Brazil (Agrofit 2015) were evaluated with regard to their effects on the predator $N$. baraki upon realistic exposure via contact with contaminated surfaces and ingestion of contaminated prey to identify which compounds are likely to be compatible with biological control of the coconut mite, exhibiting little or no negative impact on the biocontrol agent. The results of our research showed negative effects of abamectin on the oviposition, post-oviposition, survival curves and $\mathrm{R}_{0}$ of female $N$. baraki after exposure. Reductions in $\mathrm{R}_{0}$ and $\mathrm{r}_{\mathrm{m}}$ as well as an increase in DT were observed in the offspring of fenpyroximate-exposed $N$. baraki females. No biological parameter of $N$. baraki or their offspring was affected by azadirachtin.

Abamectin decreased the oviposition of $N$. baraki as well as its fertility. The adverse effect of abamectin on the fecundity of phytoseiid predators has been demonstrated in 


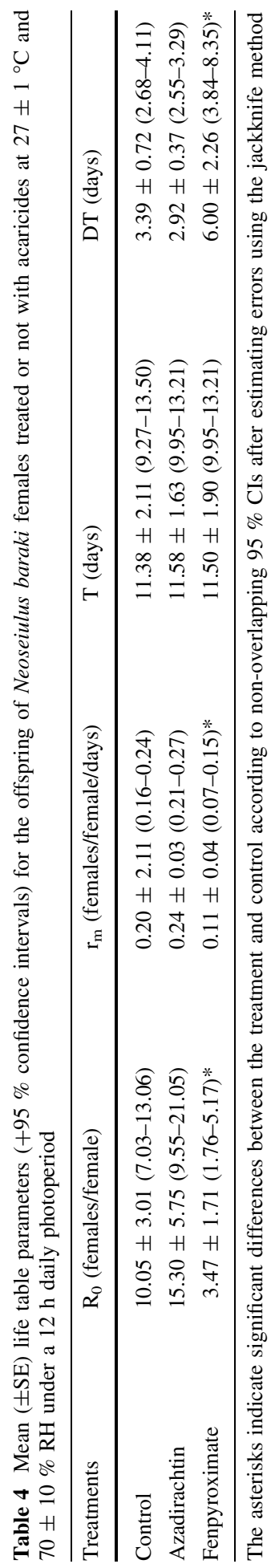


several studies (Zhang and Sanderson 1990; Ibrahim and Yee 2000; Bostanian and Akalach 2006; Nadimi et al. 2009; Lima et al. 2013b). Lima et al. (2015a) observed that abamectin exposure can compromise the consumption of A. guerreronis by N. baraki. A reduction in predator feeding may compromise its fitness. Our results also showed that the population growth rate of the offspring of abamectin-exposed females was significantly reduced. This product has been considered non-selective based on a comparison of its toxicity on $N$. baraki and coconut mite (Lima et al. 2013b).

Although fenpyroximate did not show negative effects on treated females (F0), this product interfered with the offspring of the treated females $\left(\mathrm{R}_{0}, \mathrm{r}_{\mathrm{m}}\right.$ and DT). Our findings agree with those of Hamedi et al. (2010), who reported a decreased oviposition period of fenpyroximate-treated females of the predatory mite species Phytoseius plumifer (Canestrini \& Fanzago) (Acari: Phytoseiidae), compromising its fertility and that of the subsequent generation. How the acaricides interfere with the offspring of predatory mites is unclear. However, fenpyroximate did not affect the 2 nd generation. These results suggest that the impact of fenpyroximate is minimized over the generations. In our study, the predator was exposed only once to the acaricides, which we assumed to be a realistic condition because $N$. baraki lives under the bracts and is not in contact with acaricides that do not reach this area. Nevertheless, field acaricide application is performed at short intervals (at least two times per month) (Melo et al. 2012). Thus, the effects observed here will be more persistent in the field.

Azadirachtin also does not appear to affect the biological parameters of $N$. baraki through subsequent generations (e.g., life table parameters for the first generation and $r_{i}$ for the second generation). However, Lima et al. (2013a, 2015b, 2016 found changes in the behaviour of $N$. baraki (walking behaviour, overall predator activity, mating behaviour and prey location) when exposed to azadirachtin. These authors suggested that doubts remain regarding the alleged environmental safety and selectivity of this bioinsecticide towards biological control agents.

The results obtained in this study indicate significant negative effects of abamectin and fenpyroximate on $N$. baraki. The use of abamectin and fenpyroximate resulted in adverse consequences for the biological control of A. guerreronis using $N$. baraki because both acaricides decreased predator population growth, extending to the 1 st but not the 2 nd generation of exposed mites. Curiously, azadirachtin did not exhibit significant negative effects on the predator population, which suggests its potential compatibility with biological control for the management of coconut mites. However, field experiments need to be performed using periodic acaricide applications to account for this pattern of pesticide use and to allow for possible predator behavioural changes with exposure, which has been reported elsewhere (Lima et al. 2013a, 2015b) and may result in significant negative impacts on $N$. baraki.

Acknowledgments We thank the following Brazilian agencies for their financial support: Pernambuco State Foundation for Research Aid (FACEPE), CAPES Foundation (Brazilian Ministry of Education) [PDSE/CAPES (Proc. 99999.002186/2014-04)], the National Council of Scientific and Technological Development (CNPq).

\section{References}

Agrofit (2015) Sistema de agrotóxicos Fitossanitários do Ministério da Agricultura, Pecuária e Abastecimento, http://extranet.agricultura.gov.br/agrofit_cons/principal_agrofit_cons. Accessed 03 January 2015 
Ahmadi A (1983) Demographic toxicology as a method for studying the dicofol-twospotted spider mite (Acari: Tetranychidae) system. J Econ Entomol 76:239-242

Ansaloni T, Aucejo S, Jacas JA (2007) Estimating the intrinsic rate of increase of Tetranychus urticae: which is the minimum number of immature individuals to consider? Exp Appl Acarol 41:55-59

Aratchige NS, Sabelis MW, Lesna I (2007) Plant structural changes due to herbivory: do changes in Aceria infested coconut fruits allow predatory mites to move under the perianth? Exp Appl Acarol 43:97-107

Bostanian NJ, Akalach M (2006) The effect of indoxacarb and five other insecticides on Phytoseiulus persimilis (Acari: Phytoseiidae), Amblyseius fallacies (Acari: Phytoseiidae) and nymph of Orius insidiosus (Hemiptera: Anthocoridae). Pest Manag Sci 62:334-339

Domingos CA, Melo JWS, Gondim MGC Jr, Moraes GJ, Hanna R, Lawson-balagbo LM, Schausberger P (2010) Diet-dependent life history, feeding preference and thermal requirements of the predatory mite Neoseiulus baraki (Acari: Phytoseiidae). Exp Appl Acarol 50:201-215

Fernando LCP, Waidyarathne KP, Perera KFG, De Silva PHPR (2010) Evidence for suppressing coconut mite, Aceria guerreronis by inundative release of the predatory mite, Neoseiulus baraki. Biol Control 53:108-111

Guedes RNC, Stark JD, Smagghe G, Desneux N (2016) Pesticidal stress in arthropod pests of optimized integrated pest management programs. Annu Rev Entomol 61:43-62

Hamedi N, Fathipour Y, Saber M (2010) Sublethal effects of fenpyroximate on life table parameters of the predatory mite Phytoseius plumifer. Biocontrol 55:271-278

Haq MA, Sumangala K, Ramani N (2002) Coconut mite invasion, injury and distribution. In: Fernando LCP, Moraes GJ, Wickramananda IR (eds) Proceedings of the international workshop on coconut mite (Aceria guerreronis). Coconut Research Error! Hyperlink reference not valid.Institute, Sri Lanka, pp 41-49

Helle W, Sabelis MW (1985) Spider mites: their biology, natural enemies and control. Elsevier, Amsterdam

Hosmer DW, Lemeshow S (1999) Applied survival analysis. Wiley, New York

Ibrahim YB, Yee TS (2000) Influence of sublethal exposure to abamectin on the biological performance of Neoseiulus longispinosus (Acari: Phytoseiidae). J Econ Entomol 93:1085-1089

Lima DB, Melo JWS, Gondim MGC Jr, Moraes GJ (2012) Limitations of Neoseiulus baraki and Proctolaelaps bickleyi as control agents of Aceria guerreronis Keifer. Exp Appl Acarol 56:233-246

Lima DB, Melo JWS, Guedes RNC, Siqueira HAA, Pallini A, Gondim MGC Jr (2013a) Survival and behavioural response to acaricides of the coconut mite predator Neoseiulus baraki. Exp Appl Acarol 60:381-393

Lima DB, Monteiro VB, Guedes RNC, Siqueira HAA, Pallini A, Gondim MGC Jr (2013b) Acaricide toxicity and synergism of fenpyroximate to the coconut mite predator Neoseiulus baraki. Biocontrol 58:595-605

Lima DB, Melo JWS, Gondim MGC Jr, Guedes RNC, Oliveira JEM (2015a) Acaricide-impaired functional predation response of the phytoseiid mite Neoseiulus baraki to the coconut mite Aceria guerreronis. Ecotoxicology 24:1124-1130

Lima DB, Melo JWS, Guedes NMP, Gontijo LM, Guedes RNC, Gondim MGC Jr (2015b) Bioinsecticidepredator interactions: azadirachtin behavioral and reproductive impairment of the coconut mite predator Neoseiulus baraki. Plos One. doi:10.1371/journal.pone.0118343

Lima DB, Oliveira HKV, Melo JWS, Gondim MGC Jr, Guedes RNC, Pallini A, Oliveira JEM (2016) Acaricides impair prey location in a predatory phytoseiid mite. J Appl Entomol. doi:10.1111/jen.12327

Maia AHN, Luiz AJB, Campanhola C (2000) Statistical inference on associated fertility life table parameters using Jackknife technique: Computational aspects. J Econ Entomol 93:511-518

McMurtry JA, Croft BA (1997) Life styles of phytoseiid mites and their roles in biological control. Annu Rev Entomol 42:291-321

McMurtry JA, de Moraes GJ, Famah Sourassou N (2013) Revision of the lifestyles of phytoseiid mites (Acari: Phytoseiidae) and implications for biological control strategies. Syst Appl Acarol 18:297-320

Melo JWS, Lima DB, Pallini A, Oliveira JEM, Gondim MGC Jr (2011) Olfactory response of predatory mites to vegetative and reproductive parts of coconut palm infested by Aceria guerreronis. Exp Appl Acarol 55:191-202

Melo JWS, Domingos CA, Pallini A, Oliveira JEM, Gondim MGC Jr (2012) Removal of bunches or spikelets is not effective for the control of Aceria guerreronis. HortScience 47:1-5

Monteiro VB, Lima DB, Gondim MGC Jr, Siqueira HAA (2012) Residual bioassay to assess the toxicity of acaricides against Aceria guerreronis (Acari: Eriophyidae) under laboratory conditions. J Econ Entomol 105:1419-1425

Moore D, Howard FW (1996) Coconuts. In: Lindquist EE, Sabelis MW, Bruin J (eds) Eriophyoid mites: Their biology, natural enemies and control. Elsevier, Amsterdam, pp 561-570 
Nadimi A, Kamali K, Arbabi M, Abdoli F (2009) Selectivity of three miticides to spider mite predator, Phytoseius plumifer (Acari: Phytoseiidae) under laboratory conditions. AgricSci China 8:326-331

Navia D, Gondim MGC Jr, Aratchige NS, Moraes GJ (2013) A review of the status of the coconut mite, Aceria guerreronis (Acari: Eriophyidae), a major tropical mite pest. Exp Appl Acarol 59:67-94

Negloh K, Hanna R, Schausberger P (2008) Comparative demography and diet breadth of Brazilian and African populations of the predatory mite N. baraki, a candidate for biological control of coconut mite. Biol Control 46:523-531

Negloh K, Hanna R, Schausberger P (2011) The coconut mite, Aceria guerreronis, in Benin and Tanzania: occurrence, damage and associated acarine fauna. Exp Appl Acarol 55:174-361

Ramaraju K, Natarajan K, Babu PCS, Palnisamy S, Rabindra RJ (2002) Studies on coconut eriophyid mite, Aceria guerreronis Keifer in Tamil Nadu, Índia. In: Fernando LCP, Moraes GJ, Wickramananda IR (eds) Proceedings of the international workshop on coconut mite (Aceria guerreronis). Coconut Research Institute, Sri Lanka, pp 13-31

Rezende D, Melo JWS, Oliveira JEM, Gondim MGC Jr (2016) Estimated crop loss due to coconut mite and financial analysis of controlling the pest using the acaricide abamectin. Exp Appl Acarol. doi:10.1007/ s10493-016-0039-0

Sabelis MW (1985) Reproductive strategies. In: Helle W, Sabelis MV (eds) Spider mites, their biology, natural enemies and control. Elsevier, Amsterdam, pp 265-278

Saito Y (1979) Comparative studies on life histories of three species of spider mites (Acarina: Tetranychidae). Appl Entomol Zool 14:83-94

SAS Institute (2008) SAS/STAT User's guide, version 8.02, TS level 2 MO. SAS Institute Inc. Cary, North Carolina

Silva VF, França GV, Melo JWS, Guedes RNC, Gondim MGC Jr (2016) Targeting hidden pests: acaricides against the coconut mite Aceria guerreronis. J Pest Sci. doi:10.1007/s10340-016-0776-1

Solomon MG, Cross JV, Fitzgerald JD, Campbell CAM, Jolly RL, Olszak RW, Niemczyk E, Vogt H (2010) Biocontrol of pests of apples and pears in Northern and Central Europe-3. Predators Biocontrol Sci Technol 10:91-128

Stark JD, Wennergren U (1995) Can population effects of pesticides be predicted from demographic toxicological studies? J Econ Entomol 88:1089-1096

Stark JD, Tanigoshi L, Bounfour M, Antonelli A (1997) Reproductive potential: its influence on the susceptibility of a species to pesticides. Ecotoxicol Environ Safety 37:273-279

Walthall WK, Stark JD (1997) Comparison of two population level ecotoxicological endpoints: the intrinsic $\left(\mathrm{r}_{\mathrm{m}}\right)$ and instantaneous $\left(r_{i}\right)$ rates of increase. Environ Toxicol Chem 16:1068-1073

Watanabe MA, Moraes GJ, Gastaldo I Jr, Nicolella G (1994) Controle biológico do ácaro rajado com ácaros predadores fitoseídeos (Acari: Tetranychidae, Phytoseiidae) em culturas de pepino e morango. SciAgric 51:75-81

Zhang Z, Sanderson JP (1990) Relative toxicity of abamectin to the predatory mite Phytoseiulus persimilis (Acari: Phytoseiidae) and two-spotted spider mite (Acari: Tetranychidae). Annu Rev Entomol 83:1783-1793 